\section{JSCN T \\ Journal of Sustainable Construction \\ Materials and Technologies}

\title{
Potential Barriers to Sustainable Construction: A Model Proposal
}

\author{
Tülay Çivici ${ }^{\mathrm{a},}$, , Resul Özlük ${ }^{\mathrm{b}}$ \\ ${ }^{a}$ Balıkesir üniversitesi, Mimarlık Fakültesi, Mimarlık Bölümï \\ ${ }^{b}$ Balıkesir Üniversitesi, Fen Bilimleri Enstütüs, Mimarlı ABD yüksek Lisans Programı
}

Manuscript Received August 9, 2020; Accepted September 18, 2020

\begin{abstract}
In this study, it is aimed to identify potential barriers to sustainable construction in the Turkish Construction Industry. To this end, a survey was conducted covering architects, civil engineers and other (project manager, mechanical engineers, ets.) professionals working in the Turkish Construction Industry. Based on the data obtained from the survey, the scale of "Potential Barriers to Sustainable Construction" has been developed. Explanatory factor analysis was performed first to determine the factor structure of the research scale. As a result of the explanatory factor analysis, information deficiency barrier, education disability barrier, high investment cost barrier, awareness barrier, academic inadequacy barrier, insufficient legal framework barrier, inadequate incentive barrier was identified as potential barriers to sustainable construction. The findings show that participants see the education and awareness barrier on sustainability as a higher level than investment costs compared to other factors. The results of this study; it is thought that it will make important contributions to the literature by revealing the factors that prevent sustainable practices in the Turkish Construction Industry and by enriching the developed scale with different and various factors in future studies.
\end{abstract}

Keywords:Sustainable Construction, Barriers, Factor Analysis.

\section{Introduction}

Approximately $30 \%$ of the construction industry in GNP (gross national product) has an important place in Turkish Economy [1]. The construction industry, which has a wide field of activity, contributes to employment at a high rate with its practice of focusing on people. In addition, it affects human life significantly with its structures produced in different subjects and contents. In this broad perspective, it contributes to the human and its environment with its production, on the other hand it poses a threat with the resource it consumes [2].

A large amount of energy and resources are needed at different stages of the construction process [2,3]. The consumption of energy resources needed in this process causes biological and chemical damages to the environment [4]. Researches [5,6] suggests that the construction industry is responsible for 50\% of the raw material obtained from nature, $40 \%$ of global energy and $16 \%$ of water, and $50 \%$ of waste generated. According to 2010 data, $45 \%$ of world energy and $50 \%$ of water are used by buildings [7] Environmental effects; the contribution of building construction to global pollution is $23 \%$ to air pollution, $50 \%$ to climate change, $40 \%$ to water pollution, $50 \%$ to depletion in the ozone layer [8,7]. The impacts of buildings and communities in cities, which are the outputs of the building production process, extend to climate change [4]. Studies have shown that adopting sustainable construction will result in a significant reduction in greenhouse emissions from the construction industry [9]. These environmental problems caused by the construction industry can be significantly

* Corresponding author. Tel.: 0-266-6121239.

E-mail address: tulaycivici@gmail.com (T. Çivici)

https://doi.org/10.29187/jscmt.2020.48 
reduced by changes in practices [7]. Therefore, the construction industry has important responsibilities in protecting human and environmental health. Conscious of this responsibility, considering the social, economic and environmental impacts, it is important to produce in accordance with the requirements of the age. However, the integration of sustainability into the construction of building is problematic. Sustainable construction requires the integrated handling and planning of all technical and institutional processes of building production phases such as planning and design of projects, resource planning. Studies have shown that sustainable construction can provide environmental, social and economic benefits to users, investors, contractors, workers and society as a whole [10]. However, a number of potential barriers are encountered in the adoption / implementation of sustainable construction $[9,10]$ defining the barriers to sustainable construction, creating working environments where the construction industry participants adopt sustainability, is an important step in expanding and implementing a sustainable strategy that will minimize difficulties.

This study aims to identify potential barriers to sustainability in the Turkish Construction Industry. In order to achieve this goal, a questionnaire was conducted for the professionals (architects, civil engineers and others) involved in construction projects in Balikesir. Based on the data obtained as a result of the survey, the factors preventing sustainable construction practices were identified in the first stage. In the second stage, the scale of "Potential Barriers to Sustainable Construction" was developed with the help of these factors. Reliability and validity analysis of this scale was performed. This scale is expected to contribute to the literature in the field of construction management.

\subsection{Potential barriers to sustainability in the construction industry}

The concept of sustainability, which was first included in the World Nature Charter document adopted by the World Nature Conservation Association (IUCN) in 1982, should be managed in a way that manages the optimum sustainability of the ecosystems, organisms, land, sea and atmospheric resources, but this should be done in a way that does not endanger the integrity of ecosystems and species [11]. The most common definition of sustainability concept was defined in the Brutland Report in 1987 as "meeting today's needs without harming the ability of future generations to meet their own needs". This definition shows that environmental social issues are as important as economic issues, and human natural and economic conditions are interconnected [12]. The concept of sustainability, which is perceived as the ability to sustain the functions, processes and productivity of ecological systems in the future, can only be achieved by using the resources offered by nature at a speed that allows them to be renewed spontaneously [13].

Researchers unite on the negative impact of the construction industry on the natural environment $[3,8,9,10]$. Sustainable construction requires designers and contractors to implement building applications that will not have a negative impact on the environment in the long term. It also offers sustainable construction applications as a guiding paradigm for developing a new generation of built environment [14]. Du Plesiss $[15,16]$ defined sustainable construction as a holistic process aimed at restoring and maintaining harmony between natural and built environments, creating settlements that reaffirm human dignity and promote economic equality. It includes the implementation of a sustainable life in a building life cycle, from the planning, construction of the building, extraction of raw materials, production and making it into building materials, use of the building, demolition and waste management [17]. Unlike its traditional process, in addition to its performance, quality, cost and criteria, resource consumption, environmental degradation and healthy environmental criteria should be calculated in the production process $[18,19]$. Kilbert [18,19] principles of sustainable construction, 1) Reduce resource consumption (reduce), 2) Reuse resources (reuse) (conserve), 3) Use of renewable or recyclable resources (renew / recycle), 4) Protection of natural environment (nature), 5) Eliminate toxics (toxics), 6) Apply life-cycle costing (economics), 7) Focus on quality (quality). The goal for sustainable construction is to apply the sustainability criteria throughout the life cycle of a building from the enterprise phase to the demolition from planning to the completion of construction projects $[2,3]$.

The subject of sustainability in the construction industry, which has a wide research area, has been studied by many researchers from different perspectives. Studies on the adoption and implementation of sustainable construction have been undertaken, emphasizing the importance of revealing potential barriers $[9,10,14]$.Davies and Davies [14], emphasized that there are difficulties preventing the development of sustainable construction which are the unwillingness of customers, the lack of correct information, the absence of sustainable building materials, insufficient capacity for the execution of sustainable construction projects, insufficient expertise in sustainable designs, cost results, and professional barriers. Some researchers [20] perceived cost consequences as major barriers to ignoring economic benefits. According to Hakkinen and Belloni [21], compared to traditional 
practices, it poses a high rate of initial investment costs and risks associated with unforeseen costs in the production process, which prevents sustainable construction practices. Hwang and Tan [22] found that the sustainable construction project did not have enough awareness about the lack of communication and interest among the project team members, the benefits of green buildings, as well as the lack of customer and market demand. Similarly, Shafii et al. [23] lists the lack of awareness in sustainable construction, lack of education on sustainable design and construction as among the most important barriers. In addition, the researcher [23] suggested that high cost perception, low price offers due to difficult tender processes, lack of professional capacity and lack of regulatory rules are important obstacles to sustainable construction. Hakkinen and Belloni [21] argue that the difficulties encountered in organizational and institutional processes such as the attitude of professionals, the total cost of alternative energy sources, customer control on design, cost assessment and reflection of design practices by architects, and the absence of a rating tool to measure building sustainability are important barriers. Bueren and Priemus [24] argue that sustainable construction offers significant opportunities in its study within the scope of the Dutch Construction Industry, but is inadequate in practice. He emphasized that the main reason for this is not the technical factors, but the institutional factors underlying the fact that sustainable construction has not yet been able to force a definitive leap forward. Researchers [24] stressed the necessity to reveal the institutional processes that affect the decision of the construction industry actors regarding the implementation of sustainable construction.

Williams and Dair [20] argued that in the vertical hierarchy of sustainable construction practices in England, there is both top-down and bottom-up pressure, but most new projects have little sustainability. Researchers [20] argue that customer demand is a widely accepted obstacle, and execution without full support for sustainable concepts is the biggest barriers. It also suggests that real and perceived costs and many factors such as inadequate expertise can be effective. Ametepeya, et al. [25], in his study, where he proposed his suggestions to identify prioritize and overcome potential barriers to the successful implementation of sustainable construction in the Ghana construction industry. It has grouped it under six components, which include resistance to cultural change, lack of government commitment, concern for high investment costs, lack of professional knowledge and lack of legislation. These barriers are; financial barriers, political barriers, management / leadership barriers, technical barriers, socio-cultural barriers, information / awareness barriers. Darko and Chan [26] found that the lack of demand for sustainable buildings, the inability to promote sustainable construction, the higher initial cost, the lack of integrated design, the lack of public awareness, and the lack of government support are a common set of barriers. Aghimien et al. [28] argued that the adoption of sustainability in developing countries is low in his study, which emphasizes that construction activities pose a danger to the environment. In his study, which was conducted specifically for the Zambia Construction Industry, he argued that high concern for investment costs, lack of local green certificates, lack of government policies or support, and lack of financial incentives are important obstacles to sustainable construction. Susanti, et al. [28] based on the perception of contractors within the scope of infrastructure development projects in Indonesia, potential barriers in sustainable construction practices are predominantly related to financial and economic aspects. It suggests that it includes factors related to the limited skills and expertise of workers and the lack of communication between the parties involved in the project. Osuizugbo et al. [9] is to assess the potential barriers to the effective adoption of sustainable construction practice in the Nigerian Construction Industry, to explore how these barriers can be overcome and thereby evaluate them to achieve sustainable construction in the country. The results were determined as the weakness of government support, the lack of laws and regulations, the lack of sustainable construction demand from customers, the low level of sustainable construction awareness and the fear of adopting sustainable construction in the Nigerian Construction Industry. Hwang et al. [22] sought to analyze the adoption of sustainable construction from the perspective of small contractors. As a result of the analysis of the data obtained from the survey study conducted with the participation of the small Singapore-based contractor, the researchers reported that the need for additional investment, slow return on investment, lack of incentives, limited knowledge about sustainable construction, the tendency to maintain current practices and the inadequacy of customers' demands were the first six factors. Research results revealed that financial barriers, management barriers, and information barriers are more critical for small contractors than for large contractors.

\section{Material and Method}

In the first part of the questionnaire form prepared within the scope of the study, there are questions about demographic characteristics (age, gender, marital status, educational status). A categorical evaluation was made for demographic variables. The second part includes 35 questions / statements to identify potential barriers to sustainable construction. For the questions / statements in this section, the study of Hwang et al. [22] was used, and a 5 -point Likert-type scale $(1=$ strongly disagree $5=$ strongly agree $)$ was used for evaluation. 
The sample of the research consists of professionals (architects, civil engineers and others) involved in construction projects in Balikesir. The population of the study has been determined as professionals who are members of professional association (chamber of architects, chamber of civil engineering, etc.) in Balıkesir. 2096 professionals (architects, civil engineers, etc.) who are members of professional associations in Balıkesir province have been identified. To determine the sample size, the table created by Yazıcıoğlu and Erdoğan [29] was used. In this context, the design etc. of the practical areas of some of the professionals who are members of the professional associations. 135 participants were reached for the survey study. 21 of the participants did not want to participate in the survey. The data obtained as a result of the survey conducted with 114 participants were analysed by SPSS 22 and AMOS 20 statistical package programs.

Firstly, the demographic characteristics of the participants and the reliability of the scale used were determined. Afterwards, factor analysis was used in the analysis of the data obtained through the survey study. Factor analysis was performed in two stages: exploratory factor analysis, confirmatory factor analysis. Using explanatory and confirmatory factor analysis, potential barriers to sustainable construction have been identified. The variable structure was determined by explanatory factor analysis and the relationship of these determined variables with the variable of barriers to sustainable construction was revealed by confirmatory factor analysis.

\section{Results and Discussion}

\subsection{Demographic Characteristics}

Table 1 includes demographic characteristics of the participants. $43 \%$ of the total 114 participants are $43 \%$ architects, 37\% civil engineers and 19\% other professionals (electrical engineers, mechanical engineers). When the age ranges of the participants are analyzed, it constitutes $59 \%$ of the $21-30$ age group participants, $23 \%$ of the $31-40$ age group, $12 \%$ of the $41-50$ age group, and $6 \%$ of the 51-over age group. When the genders of the participants are examined, $43 \%$ are female and $66 \%$ are male.

Table 1. Demographic characteristics of the participants

\begin{tabular}{llll}
\hline Demographic charactesitics & Frequency & $\begin{array}{l}\text { Percent } \\
(\%)\end{array}$ \\
\hline Age & $21-30$ & 67 & 59 \\
& $31-40$ & 26 & 23 \\
& $41-50$ & 14 & 12 \\
& 50-over & 7 & 6 \\
\multirow{5}{*}{ Pender } & Female & 39 & 34 \\
& Male & 75 & 66 \\
& Architect & 49 & 43 \\
& Civil Engineer & 42 & 37 \\
& Other (project manager, mechanical engineers, ets.) & 22 & 19 \\
\hline
\end{tabular}

\subsection{Factor Analysis}

Two-stage factor analysis, including explanatory factor analysis and confirmatory factor analysis, was applied to the data obtained from the survey study. To do this, first of all, a reliability analysis is required to measure the consistency of the answers given to the questionnaire. As a result of the reliability analysis, Cronbach's Alpha $(\alpha)$ coefficient was found as 0.94 . This value shows that the responses to the questionnaire are highly reliable $(\alpha \geq 0.70)$ [30].

KMO (Kaiser-MeyerOlkin) and Bartlett tests were conducted to measure the sampling adequacy of the data set. The suitability of the sample and the distribution of the data were analyzed. KMO value in the study was obtained as 0.839 . Since this value is greater than 0.70 for the KMO value, the data obtained are determined to be suitable for factor analysis (Table 2). 
Table 2. KMO and Bartlett test values

\begin{tabular}{lll}
\hline Sample Measurement Value Sufficiency (KMO) & 0.839 \\
\hline Bartlett Test & Chi-Square & 1983.551 \\
& df & 496 \\
& Sig. & 0.000 \\
\hline
\end{tabular}

Bartlett test result shows that chi-square $1983.551(\mathrm{p}=0.000)$ value is suitable for factor analysis. The values obtained from KMO and Barlett tests were interpreted as the sample size was sufficient to apply factor analysis and the factor analysis was generalizable. In the next section, two-step factor analysis, namely explanatory factor analysis and confirmatory factor analysis, was performed. Explanatory factor analysis is a method used to reduce a large number of interrelated variables to fewer dimensions [31]. In the second stage, it is aimed to test the factor structure of the research scale with confirmatory factor analysis over different models. Explanatory factor analysis is used in the creation of measurement tools (questionnaire, test, etc.), confirmatory factor analysis is used in scale development and validity analysis [31].

Explanatory factor analysis was performed first to determine the factor structure of the research scale. Although there is no consensus about factor load values in the explanatory factor analysis, it is widely accepted that the sample varies according to the sample size. In this study, considering the sample size, the factor load value of the scale items was evaluated with a limit value of 0.50 and items below this value were removed. However, since the factor load of the SB23 item was close to the limit value, it was included in the study. In addition, items that give high load values to more than one factor are excluded from the analysis. In this case, analyzes were made with 23 items (Table 3). As a result of the explanatory factor analysis, items were collected under 7 factors. Factor loads are $1^{\text {st }}$ factor between $0.731-0.694,2^{\text {nd }}$ factor between $0.721-0.542,3^{\text {rd }}$ factor between $0.868-0.765,4^{\text {th }}$ factor between $0.856-0.543,5^{\text {th }}$ factor between $0.840-0.835,6^{\text {th }}$ factor $0.858-0.827,7^{\text {th }}$ factor received loads ranging from $0.860-0.450$. Contribution of factors to total variance $13.517 \%$ for the $1^{\text {st }}$ factor, $10.372 \%$ for the $2^{\text {nd }}$ factor, $10.318 \%$ for the $3^{\text {rd }}$ factor, $10.298 \%$ for the $4^{\text {th }}$ factor, $8.962 \%$ for the $5^{\text {th }}$ factor, $6^{\text {th }}$ factor $8.328 \%, 7.578 \%$ for the $7^{\text {th }}$ factor. The total contribution of 7 factors determined to variance was $69.379 \%$. The $1^{\text {st }}$ factor information deficiency barrier (IDB) obtained as a result of the explanatory factor analysis, the $2^{\text {nd }}$ factor education disability barrier (EDB), the $3^{\text {rd }}$ factor high investment cost barrier (HCB), the $4^{\text {th }}$ factor awareness barrier (AWB), the $5^{\text {th }}$ factor the academic inadequacy barrier (AIB), the $6^{\text {th }}$ factor was named as the insufficient legal framework barrier (LFB), the $7^{\text {th }}$ factor was the inadequate incentive barrier (IIB). When the averages of the items are examined, it is seen that the highest value is "Insufficient knowledge of customers about sustainable construction" $(\overline{\mathrm{x}}=4.12)$ and the lowest value is "lack of professional skills / designers in sustainability" $(\overline{\mathrm{x}}=3.68)$ (Table 3$)$.

Table 3. Explanatory factor analysis.

\begin{tabular}{|c|c|c|c|c|}
\hline & & $\begin{array}{l}\text { Factor } \\
\text { load }\end{array}$ & $\begin{array}{l}\text { Cronbach's } \\
\text { Alpha }(\alpha)\end{array}$ & $\begin{array}{l}\text { Average } \\
(\overline{\mathrm{x}})\end{array}$ \\
\hline \multicolumn{5}{|c|}{ Factor 1 Information Deficiency Barrier (IDB) } \\
\hline \multicolumn{5}{|c|}{ Variance rate announced: 13.517 Cumulative 13.517} \\
\hline \multicolumn{5}{|c|}{ Cronbach's Alpha $(\alpha): 0.848$} \\
\hline SB1 & Lack of "green" material and lack of knowledge in suppliers. & 0.731 & 0.812 & 3.74 \\
\hline SB2 & Lack of sufficient knowledge of the public about sustainable construction & 0.719 & 0.830 & 4.09 \\
\hline SB3 & Lack of education / training related to sustainable construction. & 0.714 & 0.807 & 3.99 \\
\hline SB4 & Lack of sustainable sample projects to be used in marketing. & 0.708 & 0.835 & 3.74 \\
\hline SB5 & Limited knowledge of sustainable construction. & 0.694 & 0.801 & 3.88 \\
\hline \multicolumn{5}{|c|}{ Factor 2 Education Disability Barrier (EDB) } \\
\hline \multicolumn{5}{|c|}{ Variance rate announced: 10.372 Cumulative: 23.889} \\
\hline \multicolumn{5}{|c|}{ Cronbach's Alpha $(\alpha): 0.813$} \\
\hline SB6 & Lack of professional skills / designers in sustainability. & 0.721 & 0.716 & 3.68 \\
\hline SB7 & Lack of a state-financed training program to improve the built environment. & 0.730 & 0.776 & 3.94 \\
\hline SB8 & $\begin{array}{l}\text { Lack of educational institutions to prepare the future workforce of sustainable } \\
\text { construction. }\end{array}$ & 0.641 & 0.801 & 4.01 \\
\hline SB9 & Lack of experts in sustainable construction. & 0.542 & 0.758 & 3.80 \\
\hline \multicolumn{5}{|c|}{ Factor 3 High Investment Cost Barrier (HCB) } \\
\hline \multicolumn{5}{|c|}{ Variance rate announced: 10.318 Cumulative: 34.207} \\
\hline \multicolumn{5}{|c|}{ Cronbach's Alpha $(\alpha)$ : 0.869} \\
\hline SB10 & Need extra investment for sustainable construction. & 0.868 & 0.770 & 4.01 \\
\hline SB11 & The first investment costs of sustainable construction are high. & 0.865 & 0.786 & 3.94 \\
\hline SB12 & The total cost of sustainable construction is high. & 0.765 & 0.883 & 3.94 \\
\hline
\end{tabular}




\begin{tabular}{|c|c|c|c|c|}
\hline \multicolumn{5}{|c|}{$\begin{array}{l}\text { Factor } 4 \text { Awareness Barrier (AWB) } \\
\text { Variance rate announced: } 10.298 \text { Cumulative: } 44.505 \\
\text { Cronbach's Alpha }(\alpha): 0.768\end{array}$} \\
\hline SB13 & Stakeholders resilience to change in sustainable construction. & 0.856 & 0.668 & 3.90 \\
\hline SB14 & Insufficient knowledge of professionals on sustainable construction. & 0.620 & 0.683 & 3.77 \\
\hline SB15 & Not being aware of the benefits of sustainable construction of our company. & 0.599 & 0.748 & 3.95 \\
\hline SB16 & Insufficient knowledge of customers about sustainable construction. & 0.543 & 0.741 & 4.12 \\
\hline \multicolumn{5}{|c|}{$\begin{array}{l}\text { Factor } 5 \text { Academic Inadequacy Barriers (AIB) } \\
\text { Variance rate announced: } 8.962 \text { Cumulative: } 53.467 \\
\text { Cronbach's Alpha }(\alpha): 0.854\end{array}$} \\
\hline SB17 & $\begin{array}{l}\text { Lack of sufficient academic information on sustainable construction in educational } \\
\text { institutions. }\end{array}$ & 0.840 & - & 3.86 \\
\hline SB18 & Insufficient understanding of green building aesthetics in educational institutions. & 0.835 & - & 3.91 \\
\hline \multicolumn{5}{|c|}{$\begin{array}{l}\text { Factor } 6 \text { Insufficient Legal framework barrier (LFB) } \\
\text { Explained variance ratio: } 8.328 \text { Cumulative: } 61.794 \\
\text { Cronbach's Alpha }(\alpha): 0.824\end{array}$} \\
\hline SB19 & Implementing regulations for sustainable construction. & 0.858 & - & 3.76 \\
\hline SB20 & Lack of legal obligations for sustainable construction. & 0.827 & - & 3.79 \\
\hline \multicolumn{5}{|c|}{$\begin{array}{l}\text { Factor } 7 \text { Inadequate Incentive Barrier (IIB) } \\
\text { Variance rate announced: } 7.578 \text { cumulative: } 69.372 \\
\text { Cronbach's Alpha }(\alpha): 0.690\end{array}$} \\
\hline SB21 & No reward system for sustainable construction applications. & 0.860 & 0.619 & 3.79 \\
\hline SB22 & Insufficient incentives such as low interest loans. & 0.589 & 0.628 & 3.76 \\
\hline SB23 & Lack of easy legal framework for sustainable construction. & 0.450 & 0.583 & 3.86 \\
\hline
\end{tabular}

After determining which items were related to which factors with the explanatory factor analysis, confirmatory factor analysis was performed. It is a method to explain the relationship between variables (items) and latent variables (factors) observed with confirmatory factor analysis [32]. Confirmatory factor analysis is one of the analysis techniques that investigate factor structures in testing structures related to latent variables [33]. Factor loads represent regression values. Whether these values named with the beta $(\beta)$ coefficient are meaningful or not is expressed by the value of $\mathrm{p}(\mathrm{p} \leq 0.005)$.

CFA (Confirmatory Factor Analysis) includes comparing the fit indices of the data obtained as a result of testing the observed and unobserved variables together in order to test the validity of the factorial structure of the model. Comparative Fit Index (CFI) and Tucker-Levis Index (TLI) values from the multiple fit indexes used are greater than 0.90, Increment Fit Index (IFI) is greater than 0.90, Square Root of the Approach Error's Squares Average (RMSEA) value should be less than 0.05 and the Square Root of the Standardized Residual Squares Average (SRMR) should be less than 0.05 [32]. Fit index criteria are given in Table 5.

In confirmatory factor analysis, it is tested on different models, first level and second level [32]. In this study, based on the factors obtained as a result of the explanatory factor analysis, 7-factor Model 1 and Model 2 were created (Fig. 1,Fig. 2).

Model 1 first-order model is the model in which observed variables are grouped under unrelated factors. When factor loads expressing regression values in Fig. 1 are examined, it is seen that the highest value is between EDB and AWB $(\beta=0.80 ; p \leq 0.001)$ and between EDB and IIB $(\beta=0.76 ; p \leq 0.001)$. The lowest value was found between HCB and AID $(\beta=0.26 ; \mathrm{p} \leq 0.001)$. The existence of first-level model fit made it necessary to investigate second-level models [34]. 


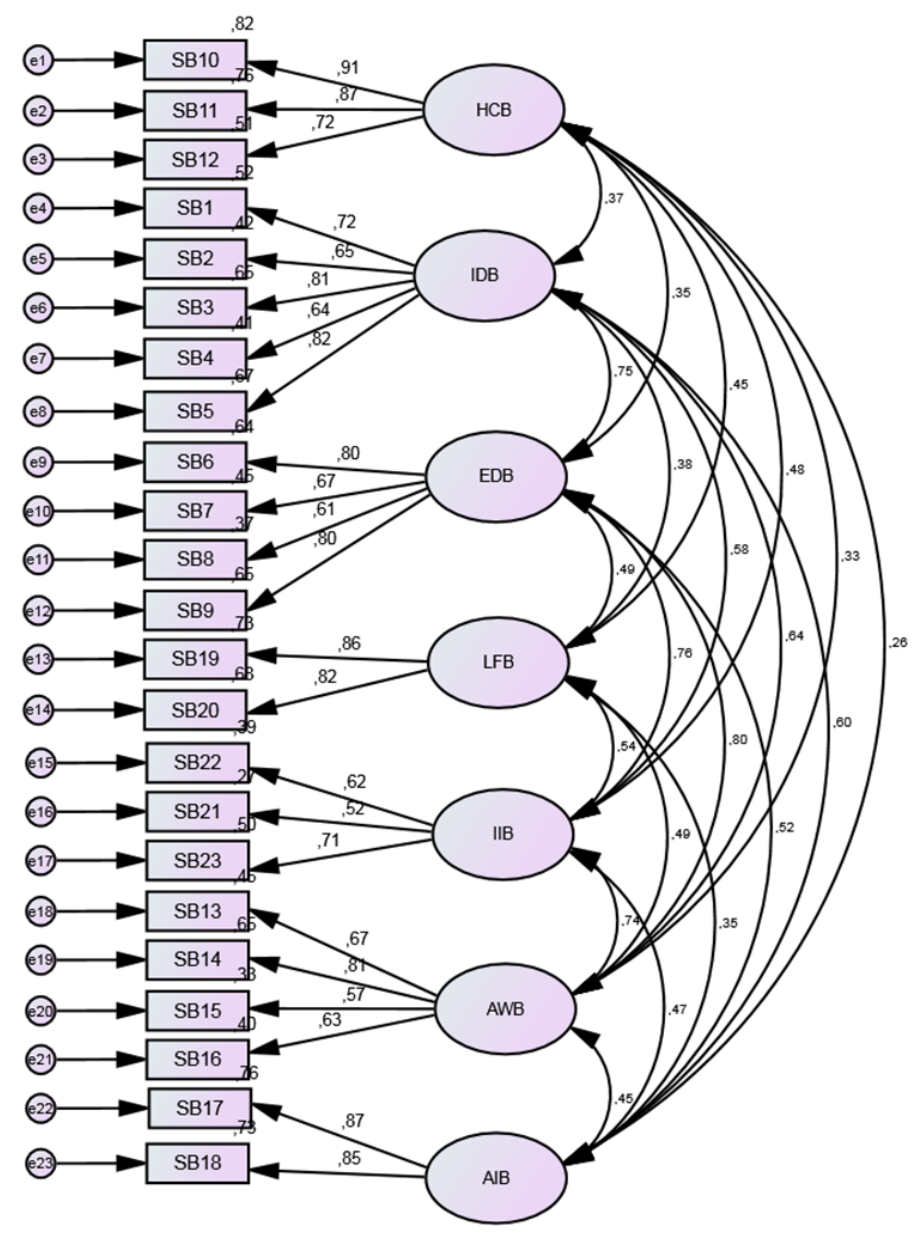

CMIN=Icmnin;DF=209; CMIN/DF=287,418/df, $p=, 000$

Fig. 1. Confirmatory factor analysis: Model 1

Model 2, A linear relationship was established between the 7-factor structure obtained by the second-level multi-factor confirmatory factor analysis and the potential barriers to sustainable construction (SCB) variable. The aim is to reveal the relationship levels between SCB and factors. Model 2, when the road coefficients are analyzed as a result of the confirmatory factor analysis conducted to determine potential barriers to sustainable construction, $\operatorname{HCB}(\beta=0.46 ; \mathrm{p} \leq 0.001)$ is the lowest value, but $\operatorname{EDB}(\beta=0.92 ; \mathrm{p} \leq 0.001)$ and $\operatorname{IIB}(\beta=0.83$; $\mathrm{p} \leq 0.001$ ) factors are high. Opening force for the HCB factor is $21 \%$; $63 \%$ for IDB; $84 \%$ for EDB; $33 \%$ for LFB, $69 \%$ for IIB; $72 \%$ for AWB; It was obtained as $35 \%$ for AIB. These statistically significant values in the positive direction obtained, it expresses the strong relationship between factors (IDB, EDB, HCB, AWB, AIB, LFB, IIB) and SCB variable.

These findings show that participants see the education and awareness barrier on sustainability as a higher level than investment costs compared to other factors. There are findings in the studies conducted [eg 21,22] that there are the first barriers to sustainable construction. The main reason for this difference between these study findings may be the sample group. It may be that the practical areas of the professional professionals who make up the sample of the study are mostly application-oriented and answer the questionnaire questions with their perspectives in this direction. In addition, the findings show that the participants think that the incentives are insufficient and that this situation constitutes barriers to sustainable construction. 


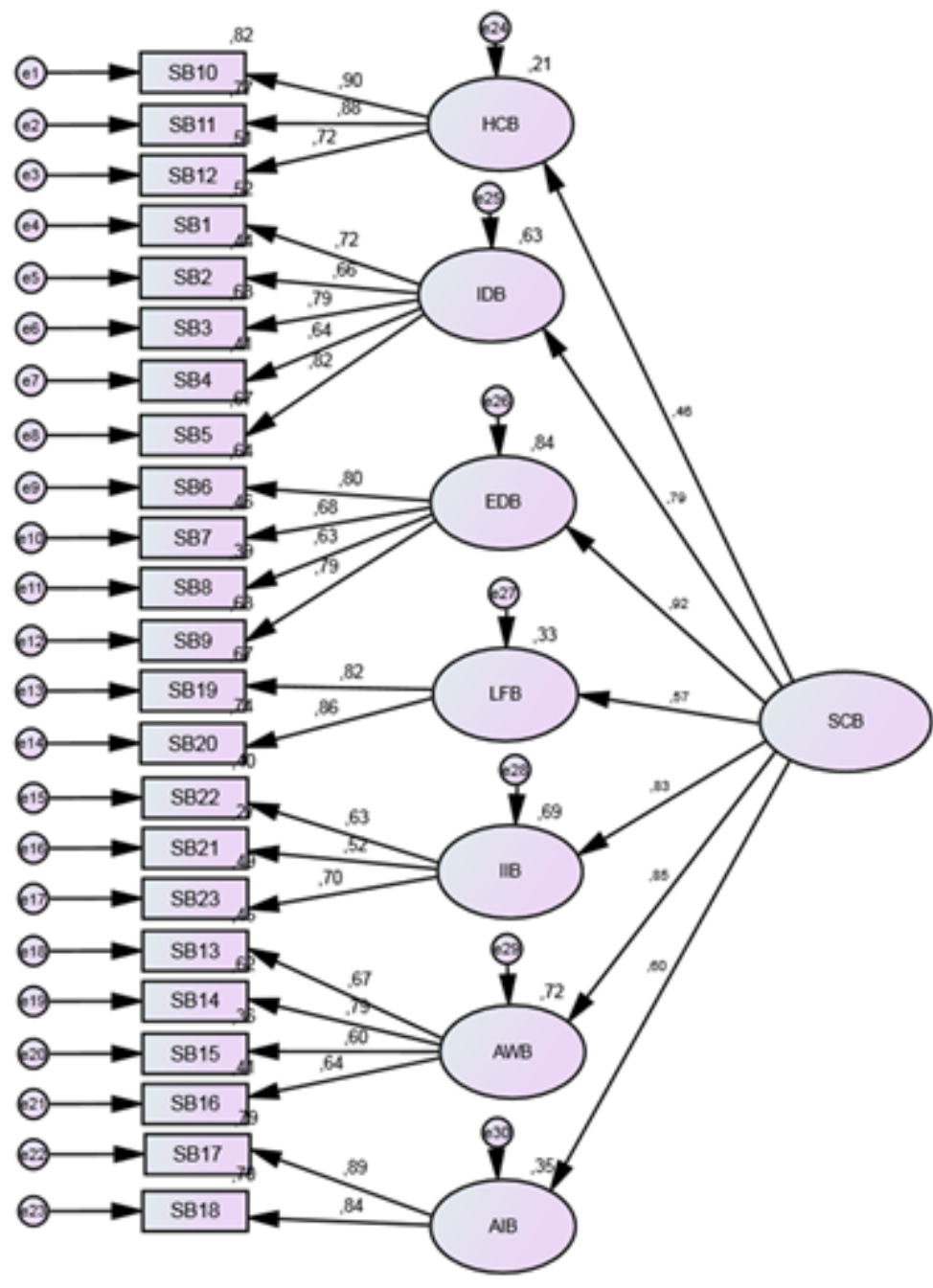

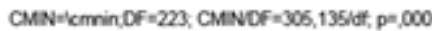

Fig. 2 Confirmatory factor analysis: Model 2

The fit index values obtained from each model as a result of the factor analysis are given in Table 5. It is seen that the values obtained are between good fit and acceptable fit values. In this form of the model, it has been determined that all path coefficients are meaningful, theoretically valid, and the model fit coefficient of determination is acceptable. In the light of these findings, it can be said that the scale developed within the scope of the study is a tool that can be used to investigate the barriers to sustainability in the construction industry.

Table 3. Fit index criteria

\begin{tabular}{lllll}
\hline $\begin{array}{l}\text { Measurement } \\
\text { (fit index criteria) }\end{array}$ & Good Compliance & $\begin{array}{l}\text { Acceptable } \\
\text { Compliance }\end{array}$ & Model 1 & Model 2 \\
\hline X2/sd & $\leq 3$ & $\leq 4-5$ & 1.375 & 1.368 \\
CFI & $\geq 0.97$ & $\geq 0.95$ & 0.934 & 0.931 \\
TLI (NNFI) & $\geq 0.95$ & $0.94-0.90$ & 0.920 & 0.922 \\
IFI & $\geq 0.95$ & $0.94-0.90$ & 0.936 & 0.943 \\
RMSEA & $\leq 0.05$ & $0.06-0.08$ & 0.058 & 0.047 \\
RMR & $\leq 0.05$ & $0.06-0.08$ & 0.070 & 0.077 \\
SRMR & $\leq 0.05$ & $0.05-0.10$ & 0.062 & 0.067 \\
\hline
\end{tabular}




\section{Conclusion}

Construction industry practices adversely affect the natural environment. This effect can be reduced by making changes in the production process. It is inevitable to follow environmentally sensitive processes in order to protect natural resources and leave the legacy they deserve to future generations. In this study conducted with this sensitivity, the issue was examined through a questionnaire applied to professional professionals (architects, civil engineers and others) who took part in construction projects, emphasizing the importance of identifying potential barriers to the development of sustainable construction. Explanatory factor analysis and confirmatory factor analysis were applied to the data obtained from the survey study. In this way, efforts were made to identify barriers to sustainability in the Turkish Construction Industry.

The findings of the explanatory factor analysis conducted in the study show that 7-factors constitute a potential barriers to sustainability in the construction industry. These are information deficiency barriers (IDB), education disability barriers (EDB), high investment cost barrier (HCB), awareness barrier (AWB), academic insufficiency barrier (AIB), insufficient legal framework barrier (LFB), inadequate incentive barrier (IIB).

Confirmatory factor analysis was performed using these factors. The relationship of factors with barriers to sustainability ( $\mathrm{SCB}$ ) in the construction industry has been investigated. The analyses performed show that there is a relationship between the 7-factors $\mathrm{SCB}$ obtained as a result of the explanatory factor analysis. In the results, it shows that the scale of "Potential Barriers to Sustainable Construction" developed within the scope of the study can be used as a measurement tool. It is thought that in the studies to be carried out in this field, it will be made an important contribution to the literature by repeating it with different participant groups, enriching the scale by dealing with various variables.

Architects, civil engineers and others (project managers, mechanical engineers, ets.) play an active role in construction applications as an important component of the construction industry. It plays an important role in transferring resources to future generations by adopting performance and sustainable practices in addition to its traditional roles in protecting and improving the quality of life of individuals and communities in the construction industry. It is important to develop and encourage various reward systems, to direct them to the applications by providing low interest loans, and to ensure that corporate processes become traceable / applicable in order for these duties they undertake in sustainable construction practices to perform successfully. Therefore, it is inevitable that legal processes should be improved and supervised through an infrastructure that will enable sustainable construction practices.

Sustainable construction requires the integrated handling, planning and management of all technical and institutional processes of building production stages. It is the first step in the formation of technical infrastructure by opening up specialization areas in sustainable construction practices and supporting them with training programs.

The fact that the province of Balıkesir, which constitutes the sample of the study, contains many natural resources, in turn, creates a concern about the increasing construction investments in recent years and the protection of the resources owned. People have an important role in this regard, from local governments to professional associations. The findings of this study are valuable in terms of determining the barriers to sustainability in the Turkish Construction Industry in particular in the province of Balıkesir, in terms of contributing to the awareness and awareness of its stakeholders (professionals, contractors, customers, suppliers, etc.).

Although this study achieved its aims, it has some limitations. The first is that the survey includes data based on the participants' knowledge, experience and perceptions. Second, the study findings are limited to the sample. However, in future studies, it will develop a perspective in developing strategies that will guide national policies by repeating these constraints with wider participation.

\section{References}

1. YEM,Türk Yapı Sektörü Raporu (Özet Rapor),Yapı-Endüstrisi Merkezi, (2010).

2. Yorgancıoğlu P., "Sürdürülebilir Yapım Kavramının Uygulamaya Aktarılmasındaki Araç, Yöntem ve Yaklaşımlara İlişskin Bir Değerlendirme”, İTÜ Fen Bilimleri, Mimarlık Anabilim Dalı, Bina Yapım Yönetimi Programı, Y. Lisans Tezi, (2004), 1-128.

3. Paker B., Taş N., "Sürdürülebilir Yapım Sürecinde Mimarın Yapısal Atık Oluşumuna Etkisinin İrdelenmesi: Bursa Örneği”, Süleyman Demirel Üniversitesi Yalvaç Akademi Dergisi, 2 (1), (2017), 88-98.

4. Vyas S., Ahmed S. and Parashar A.,"BEE (Bureau of energy efficiency) and Green Bulldıngs, International Journal of Research, 
1(3), (2014), 23-32.

5. Sev, A., Sürdürülebilir Mimarlık: Yem Yayın, İstanbul, (2009).

6. Geçer E., Şentürk İ., Büyükgüngör H., "Yeșil Bina Tasarımında Su ve Enerji Yönetimi Üzerine Uygulama Örneği”, Güfbed 9 (2), (2019), 332-343.

7. Yılmaz M., Bakış A., "Sustainability in Construction Sector World Conference on Technology", Innovation and Entrepreneurship Procedia - Social and Behavioral Sciences, 195, (2015 ), 2253 - 2262.

8. Willmott-Dixon Group, "The Impacts of Construction and the Built Environment", Briefing Notes, (2010).

9. Osuizugbo I., Oyeyipo O., Lahanmi A., Morakinyo A. Olaniyi O., "Barriers to the Adoption of Sustainable Construction", European Journal of Sustainable Development 9 (2), (2020), 150-162.

10. Khalfan M., Noor M. Maqsood A., T., Alshanbri N., Sagoo A., "Perceptions towards Sustainable Construction amongst Construction Contractors in State of Victoria, Australia”. Journal of Economics, Business and Management, 3(10), (2015), 940947.

11. Gezen, A. F., “İnşaat Sektöründe Sürdürülebilir Kent Yaşamı ve Karayolunda Uygulama Alanları”, Beykent Üniversitesi, Fen Bilimleri Enstitüsü, İnşaat Mühendisliği Anabilim Dalı, Tasarım ve Yapım Yönetimi Bilim Dalı, Y. Lisans Tezi, (2015), 1-131.

12. Al-Yami A. and Price, A. D. F., "Assessing the Feasibility of Using Value Management to Accelerate the İmplementation of Sustainability", Proceeding of the 6th International Postgraduate Research Conference in the Built And Research Institute For The Built And Human Environment, 6-7th April , 1, . (2006),765-774.

13. Yavuz A., "Sürdürülebilirlik Kavramı ve İşletmeler Açısından Sürdürülebilir Üretim Stratejileri”, Mustafa Kemal Üniversitesi Sosyal Bilimler Enstitüsü Dergisi, 7(14), (2010), 63-86.

14. Davies O.O.A, Davies I.O.E, "Barriers to Implementation of Sustainable Construction Techniques", MAYFEB Journal of Environmental Science, 2, (2017), 1-9.

15. Du Plessis, C. "A strategic framework for sustainable construction in developing countries", Construction Management and Economics, 25, (2007), 67-76.

16. Du Plessis, C., "Agenda 21 for Sustainable Construction in Developing Countries, CSIR Report BOU/ E0204, CSIR, CIB \& UNEP-IETC, Pretoria, (Erişim, 2020).

17. Yılmaz M., Bakış A., Yıldız S., “Türkiye'de Sürdürülebilir İnşaat Sektörünün Önündeki Engeller” 1.Uluslararası Mühendislik Mimarlık ve Tasarım Kongresi, 13-14 Kasım, Kocaeli, (2015).

18. Kilbert, C. J. "Establıshıng Principles and A Model for Sustainable Construction", CIB TG 16, Sustainable Construction, Tampa , Florida , Usa, November 6-9, (1994).

19. Kilbert, C. J. "Sustainable Construction: Green Building Design And Deliver". London: John Wiley And Sons, (2005), 608.

20. Williams K. and Dair C., "What is Stopping Sustainable Building in England? Barriers Experienced by Stakeholders in Delivering Sustainable Developments", Sustainable Development, 15 (3), (2007) 135-147.

21. Häkkinen T. and Belloni K., "Barriers and drivers for sustainable building Building”, Building Research and Information, 39 (3), (2011), 239-255.

22. Hwang B. G. and Tan J., "Sustainable Project Management for Green Construction: Challenges, Impact and Solutions", Construction Conference, (2012), 1-9.

23. Shafii F., Arman Z. and Ali, Othman M. Z., “Achieving Sustainable Construction in The Developing Countries of Southeast Asia”, Proceedings Of The 6th Asia-Pacific Structural Engineering And Construction Conference (APSEC 2006), Kuala Lumpur, Malaysia, 5 - 6 September (2006), 29-44.

24. Bueren E.M. and Priemus H., "Institutional barriers to sustainable construction", Environment and Planning and Design (29)1, (2002), 75-86.

25. Ametepeya O., Aigbavboab C., Ansahb K. "Barriers to successful implementation of sustainable construction in the Ghanaian construction industry", Procedia Manufacturing, ”, 6th International Conference on Applied Human Factors and Ergonomics, (2015), 1682-1689.

26. Darko A. and Chan A. P. C., "Review of Barriers to Green Building Adoption", Sustainable Development, 30, (2016), 167-179.

27. Aghimien, D., Aigbavboa, C., Oke, A. and Musenga, C., "Barriers to Sustainable construction Practices in the Zambian Construction Industry", Proceedings of the International Conference on Industrial Engineering and Operations Management Paris, France, July 26-27, (2018), 2383-2392.

28. Susanti B., Filestre S.F.H. and Juliantina I., "The Analysis of Barriers for Implementation of Sustainable Construction in Indonesia", The 2nd International Conference on Smart City Innovation, (2019), 1-10.

29. Yazıcığlu, Y. ve Erdoğan, S., SPSS Uygulamalı Bilimsel Araştırma Yöntemleri Ankara: Detay Yayıncılık, 2004.

30. Özdamar K., "Paket Programlar ile İstatistiksel Veri Analizi”, 1. Kaan Kitabevi, Eskişehir, (1999).

31. Büyüköztürk Ş., "Sosyal Bilimler için Veri Analizi”, El Kitabı (21. Bask1). Ankara: Pegem Akademi Yayınları. (2015).

32. Byrne, B.M., "Structural Equation Modeling with LISREL, PRELIS, and SIMPLIS: Basic Concepts, Applications, and Programming", Psychology Press, New York, NY., (2009).

33. Tabachnick, B. G and Fidell, L. S. "Using multivariate statistics", (6th ed.), Boston: Allyn and Bacon. (2013).

34. Canivez, G. L., "Bifactor modeling in construct validation of multifactored tests: Implications for multidimensionality and test interpretation", Principles and methods of test construction: Standards and recent advancements, Gottingen, Germany: Hogrefe, (2016), 247-271. 